\title{
Research on combustion characteristics and ash properties of municipal sewage sludge
}

\author{
Wenjun Yang, Zhiwen Xu, Yungang Wang, Zhiyuan Liang, Qinxin Zhao * \\ Xi'an Jiaotong university, No.28 Xianning West Road, Xi'an, 710049 Shaanxi, China
}

\begin{abstract}
In this study, the combustion characteristic of municipal sewage sludge(MSS) was investigated using non-isothermal thermogravimetric analysis at different heating rates $\left(5^{\circ} \mathrm{C} / \mathrm{min}, 10^{\circ} \mathrm{C} / \mathrm{min}\right.$ and $\left.20^{\circ} \mathrm{C} / \mathrm{min}\right)$, and the ash properties under different combustion temperatures were studied by means of X-ray fluorescence (XRF), X-ray diffraction (XRD) and scanning electron microscope (SEM). The results indicated that there were four main stages during combustion process of MSS: dehydration, de-volatilization and combustion of volatile, combustion of char and residual organics, and burnout. The SEM micro-morphology analysis indicated that loose ash particles with porous structure gradually transformed into large aggregates with dense structure with an increase in combustion temperature from $575{ }^{\circ} \mathrm{C}$ to $1000^{\circ} \mathrm{C}$, and MSS ash sintered severely under $1000^{\circ} \mathrm{C}$ to form materials with high strength. The XRD results indicated that the main minerals in MSS ash were quartz $\left(\mathrm{SiO}_{2}\right)$ and hematite $\left(\mathrm{Fe}_{2} \mathrm{O}_{3}\right)$. Under high temperature, minerals reacted with each other to form eutectic compounds with low melting point, leading to severe sintering and melting of MSS ash.
\end{abstract}

Keywords: Municipal sewage sludge, thermogravimetric analysis, combustion, ash properties

\section{Introduction}

Municipal sewage sludge (MSS) is a solid waste generated during the treatment of municipal wastewater, which generally contains abundant combustible organic materials and a lot of toxic and harmful substances, such as viruses, bacteria, parasites and heavy metals, etc [1,2]. The amount of sewage sludge increases steadily and there are lots of difficulties during sludge treatment. With rapid development of economy and society, sewage sludge has attracted more and more attention due to its high underlying damage to environment and people's health and its potential to be used as a fuel.

The main treatment methods of sewage sludge are landfill, agricultural application, composting and incineration, but significant differences in sludge disposal are observed around the world [3-6]. Nonstandard or irregular treatments do much harm to the environment and people's health. Dried sewage sludge has a high content of combustible material and substantial calorific value leading to the practicality of using MSS as a fuel [7]. Incineration is an effective and acceptable way to achieve sludge minimization and energy recovery. During incineration, the organic matters release vast amounts of energy for people to use and hazardous substances get proper treatments. The volume and weight of sludge decrease significantly, and the viruses, bacteria and parasites get killed thoroughly [8,9]. The heavy metals in sludge are also easier to achieve centralized treatment.

Flocculants used during waste treatment processes generally contain iron $(\mathrm{Fe})$, phosphorus $(\mathrm{P})$, and alkali metals [10]. Thus a high content of $\mathrm{Fe}_{2} \mathrm{O}_{3}$ and $\mathrm{P}_{2} \mathrm{O}_{5}$ generally contained in sewage sludge ash enhances the tendency of slagging and sintering during combustion process [11]. Severe slagging directly threatens the safety operation of combustion devices and impacts the thermal efficiency seriously. It is essential to control combustion temperature below ash slagging temperature. Therefore, it is

\footnotetext{
* Manuscript received February 2, 2018; revised May 5, 2019.

Corresponding author. Tel.: +86-029-82665710; E-mail address: zhaoqx@mail.xjtu.edu.cn.

doi: 10.12720 /sgce.8.4.408-414
} 
indispensable to do enough researches on the ash properties during thermal utilization of sewage sludge.

At present, some studies about combustion of sewage sludge have been reported $[8,9]$. There are also lots of research about the co-combustion characteristics of sewage sludge and other fuels, such as biomass and coal [12-17], but the difference in components between various sewage sludge leads to the inapplicability of existing reports [18]. It's still necessary to do some research on local MSS before thermal utilization. Furthermore, ash property of sewage sludge was rarely investigated. Study on ash fusion and sintering properties of sewage sludge and palm fiber is also quite necessary.

In this work, thermogravimetric analysis was carried out to study the combustion characteristics and kinetics of sewage sludge, and X-ray fluorescence (XRF), scanning electron microscope (SEM) and Xray diffraction (XRD) analysis on combustion residues were also conducted to obtain the elemental compositions, the microstructure and mineral compositions of MSS ash respectively. The aim of this work is to investigate the combustion characteristic and ash properties of MSS, obtain the optimized combustion condition and lay the groundwork for its thermal utilization.

\section{Materials and Methods}

\subsection{Materials}

In this study, MSS was obtained from a wastewater treatment plant in Xi'an (Shaanxi Province, China). The MSS sample was dried at $105^{\circ} \mathrm{C}$ for $24 \mathrm{~h}$, milled and sieved into 50-200microns in diameter and then stored in the desiccators.

\subsection{Experimental apparatus and procedure}

Thermogravimetric analysis was conducted in a STA-409PC thermal analyzer (NETZCH, German). For each test, $10 \pm 0.5 \mathrm{mg}$ of sample was heated from room temperature to $1100^{\circ} \mathrm{C}$ in $79 \mathrm{~N}_{2} / 21 \% \mathrm{O}_{2}(\mathrm{v} / \mathrm{v} \%)$ atmosphere with a flow rate of $100 \mathrm{ml} / \mathrm{min}$ at a constant heating rate $\left(5^{\circ} \mathrm{C} / \mathrm{min}, 10^{\circ} \mathrm{C} / \mathrm{min}\right.$ and $\left.20^{\circ} \mathrm{C} / \mathrm{min}\right)$. All the experiments were carried out three times to decrease the test error, and the reproducibility was quite good. The curves of thermogravimetric mass loss (TG), differential thermogravimetric (DTG) and differential scanning calorimetry (DSC) of MSS at three heating rates were obtained.

Ash samples of MSS were prepared at $575^{\circ} \mathrm{C}$ (standard test method for ash in biomass, ASTM E 1755), $700^{\circ} \mathrm{C}, 800^{\circ} \mathrm{C}, 900^{\circ} \mathrm{C}$ and $1000^{\circ} \mathrm{C}$. The MSS sample was placed in a muffle furnace, then heated up to the final temperature at a heating rate of $10^{\circ} \mathrm{C} / \mathrm{min}$ and finally maintained at the final temperature for $4 \mathrm{~h}$.

Ash compositions of MSS at $575^{\circ} \mathrm{C}$ were conducted on an X-ray fluorescence spectrometer. The mineral phases were performed on an X-ray diffractometer (XRD), and the micro-morphology of ash samples was observed with SEM.

\section{Results and Discussion}

\subsection{Characterization of materials}

Table 1 shows the ultimate and proximate analysis and calorific values of MSS. As given in Table 1, MSS has a high ash content up to $50.3 \%$, resulting in an obvious difference in the calorific value and combustion characteristics with traditional biomasses, such as pine sawdust, wheat straw and rice straw [15-17].

Table 1. Proximate and ultimate analysis of MSS

\begin{tabular}{cccccccccc}
\hline & \multicolumn{4}{c}{ Proximate analysis/\% } & \multicolumn{3}{c}{ Ultimate analysis/\% } & \multicolumn{2}{c}{$\mathrm{Q}_{\text {net }} \cdot \mathrm{d} /$} \\
$\mathrm{M}_{\mathrm{d}}$ & $\mathrm{A}_{\mathrm{d}}$ & $\mathrm{V}_{\mathrm{d}}$ & $\mathrm{FC}_{\mathrm{d}}$ & $\mathrm{C}_{\mathrm{d}}$ & $\mathrm{H}_{\mathrm{d}}$ & $\mathrm{N}_{\mathrm{d}}$ & $\mathrm{O}_{\mathrm{d}}$ & $\mathrm{S}_{\mathrm{d}}$ & $\mathrm{MJ} \cdot \mathrm{kg}^{-1}$ \\
\hline 2.38 & 50.30 & 38.84 & 8.48 & 27.72 & 4.24 & 2.83 & 9.85 & 1.52 & 8.95 \\
\hline
\end{tabular}

Table 2. Chemical compositions of MSS ash at $575^{\circ} \mathrm{C}$

\begin{tabular}{ccccccccc}
\hline $\mathrm{SiO}_{2}$ & $\mathrm{CaO}$ & $\mathrm{Al}_{2} \mathrm{O}_{3}$ & $\mathrm{Fe}_{2} \mathrm{O}_{3}$ & $\mathrm{MgO}$ & $\mathrm{K}_{2} \mathrm{O}$ & $\mathrm{Na}_{2} \mathrm{O}$ & $\mathrm{SO}_{3}$ & $\mathrm{P}_{2} \mathrm{O}_{5}$ \\
\hline $37.9 \%$ & $5.39 \%$ & $15.9 \%$ & $14.6 \%$ & $3.51 \%$ & $3.73 \%$ & $1.16 \%$ & $1.23 \%$ & $15.0 \%$ \\
\hline
\end{tabular}


The ash compositions of MSS are shown in Table 2. The high contents of $\mathrm{Fe}_{2} \mathrm{O}_{3}$ and $\mathrm{P}_{2} \mathrm{O}_{5}$ in MSS ash mainly come from the flocculants used in wastewater treat processes, and usually cause a higher slagging tendency owing to their reactions with other components to generate complex eutectic $[10,11]$.

\subsection{Combustion characteristics of MSS}

The TG and DTG curves of MSS under $79 \mathrm{~N}_{2} / 21 \% \mathrm{O}_{2}(\mathrm{v} / \mathrm{v} \%)$ atmosphere at constant heating rates of $5^{\circ} \mathrm{C} / \mathrm{min}, 10^{\circ} \mathrm{C} / \mathrm{min}$ and $20^{\circ} \mathrm{C} / \mathrm{min}$ are presented in Fig.1(a) and Fig.1(b) respectively. And the curves at three heating rates present similar shape. There were four main stages during combustion process of MSS: dehydration, de-volatilization and combustion of volatile, combustion of char and residual organics, and burnout [19].

For a constant heating rate of $20^{\circ} \mathrm{C} / \mathrm{min}$, with the development of combustion process of MSS, there exhibited two obvious weight loss peaks in DTG curve. The first and also strongest peak between $180^{\circ} \mathrm{C}$ and $380^{\circ} \mathrm{C}$ with a peak value of $-4.62 \% / \mathrm{min}$ was primarily due to de-volatilization and combustion of most volatiles [19]. The mass loss of this stage was about $23 \%$. The second peak between $380^{\circ} \mathrm{C}$ and $660^{\circ} \mathrm{C}$ with a peak value of $-2.67 \% /$ min much weaker than the first one corresponded to a mass loss ratio of $15 \%$. The mass loss ratio much higher than the fixed carbon content of $8.48 \%$ in Table 1 indicated that the second peak was mainly for the reason of combustion of fixed carbon and residual organics with low reactivity. Conesa et al. thought that the non-degradable humus and cellulose in the cell wall [20]. The high residual mass of MSS corresponded to the higher ash content of MSS as shown in Table 1.

The effects of heating temperature on combustion characteristic were investigated by comparing the TG and DTG curves at three heating rates. With the increase in heating rate, the entire combustion process delayed, the mass loss rate increased, the temperature range widened [21]. A higher heating rate resulted in a more violent reaction with a quicker de-volatilization process. A higher heating rate also strengthened the delay of volatile release and heat transfer between samples, which caused the delay of entire mass loss process.

And the combustion characteristics parameters [22] are shown in Table 3. A combustibility index S was used as a criterion for fuel combustion characteristic. A bigger $S$ indicates a better combustion characteristic, and $S$ is defined as below:

$$
S=\frac{(d W / d t)_{\max }(d W / d t)_{\text {mean }}}{T_{i}^{2} T_{f}}
$$

where $(d W / d t)_{\max }$ is the maximum mass loss rate, $(d W / d t)_{\text {mean }}$ is the average mass loss rate, $T_{i}$ and $T_{f}$ is the ignition temperature and the burnout temperature, respectively.

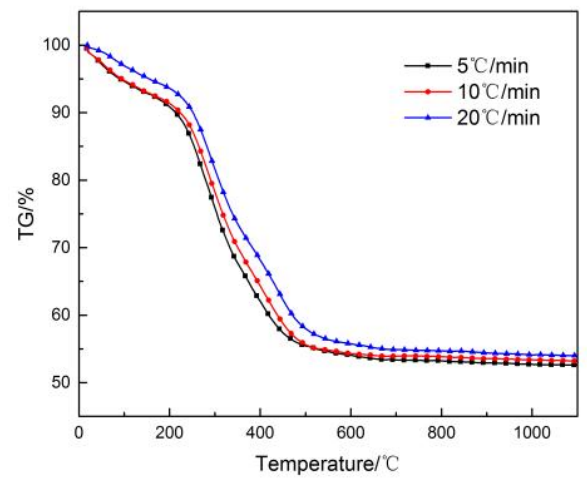

(a)

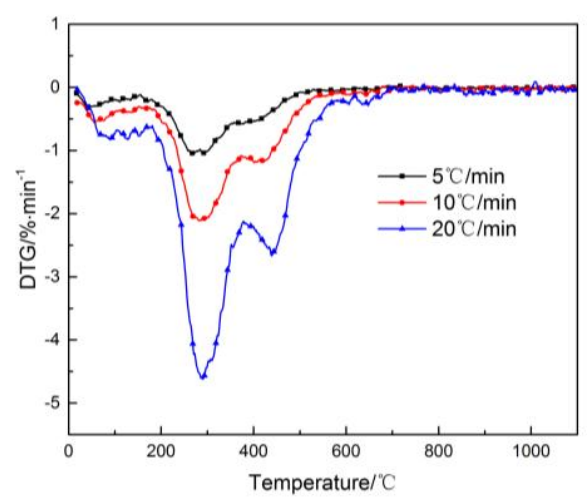

(b)

Fig.1. TG curves (a) and DTG curves (b) of MSS at different heating rates 
Table 3. Combustion parameters of MSS at different heating rates

\begin{tabular}{cccccccccc}
\hline Heating rate & $T_{i}^{\mathrm{a}}$ & $T_{f}^{\mathrm{b}}$ & $M_{f}^{\mathrm{c}}$ & $T_{1}{ }^{\mathrm{d}}$ & $D T G_{1}{ }^{\mathrm{e}}$ & $T_{2}{ }^{\mathrm{d}}$ & $D T G_{2}{ }^{\mathrm{e}}$ & $D T G_{\text {mean }}$ & $S \times 10^{7}$ \\
\hline${ }^{\circ} \mathrm{C} \cdot \mathrm{min}^{-1}$ & ${ }^{\circ} \mathrm{C}$ & ${ }^{\circ} \mathrm{C}$ & $\%$ & ${ }^{\circ} \mathrm{C}$ & $\% \cdot \mathrm{min}^{-1}$ & ${ }^{\circ} \mathrm{C}$ & $\% \cdot \mathrm{min}^{-1}$ & $\% \cdot \mathrm{min}^{-1}$ & $\% \cdot \mathrm{min}^{-2} \cdot{ }^{\circ} \mathrm{C}^{-3}$ \\
\hline 5 & 228 & 552 & 54.78 & 272 & 1.04 & 374 & 0.58 & 0.52 & 0.19 \\
10 & 231 & 636 & 53.70 & 285 & 2.11 & 408 & 1.18 & 0.88 & 0.55 \\
20 & 243 & 685 & 51.35 & 291 & 4.62 & 439 & 2.67 & 1.79 & 2.04 \\
\hline
\end{tabular}

${ }^{\mathrm{a}} T_{i}$, the ignition temperature

${ }^{\mathrm{b}} T_{f}$, the burnout temperature

${ }^{\mathrm{c}} M_{f}$, the combustion residue mass

${ }^{\mathrm{d}} T_{1}, T_{2}$, the temperature according to the first peak and the second peak

${ }^{\mathrm{e}} D T G_{1}, D T G_{2}$, the mass loss rate according to the first peak and the second peak

From Table 3, with the increase in heating rate, the ignition temperature, the temperature at the maximum mass loss rate and the burnout temperature all decreased. The increase in $\mathrm{S}$ also illustrated the strengthening of combustion process. MSS at heating rates of $5^{\circ} \mathrm{C} / \mathrm{min}, 10^{\circ} \mathrm{C} / \mathrm{min}$ and $20^{\circ} \mathrm{C} / \mathrm{min}$ had an ignition temperature of $228^{\circ} \mathrm{C}, 231^{\circ} \mathrm{C}$ and $243^{\circ} \mathrm{C}$, respectively. MSS has much complex compounds with a large temperature range of decomposition and de-volatilization leading to a lower initial release temperature of volatiles. Therefore the ignition temperature is lower than most common biomasses [1, 18].

As shown in Fig. 2, the positive and negative values of the curves represent endothermic and exothermic conditions. DSC curve of MSS at three different heating rates all had two distinct exothermic peaks corresponding to the combustion of most volatiles and the combustion of char and residual organics[18], while the peaks delayed with increasing the heating rate from $5^{\circ} \mathrm{C} / \mathrm{min}$ to $20^{\circ} \mathrm{C} / \mathrm{min}$, which was consistent with the delay of DTG peak.

When temperature went up to $900^{\circ} \mathrm{C}$, a significant endothermic tendency was observed. During this temperature range, the main reactions both physical and chemical took place between materials in MSS ash. Therefore the DSC curves could also be used to evaluate the fusion properties to some extent. A low heating rate provided enough time for various reactions to generate eutectic compounds with low melting point and also promoted the fusion or sintering process. Therefore, after burnout, DSC curves at $5^{\circ} \mathrm{C} / \mathrm{min}$ present positive values at lowest temperature and the positive values were much larger than values in the other two curves at the same temperature. Even at the heating rate of $20^{\circ} \mathrm{C} / \mathrm{min}$, the endothermic tendency was distinct after $900^{\circ} \mathrm{C}$, which indicated that the MSS ash sintered or melted severely under temperature higher than $900^{\circ} \mathrm{C}$.

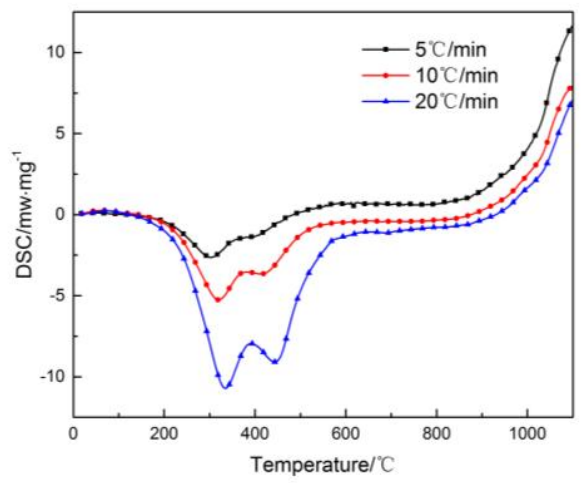

Fig.2 DSC analysis of MSS at different heating rates

\subsection{Ash properties of MSS}

To investigate the ash properties, SEM was used to obtain the microstructure of ash samples. By comparing the ash microstructure of MSS under different temperatures, the effects of temperature on ash properties were studied.

Representative SEM images of ash samples of MSS at $575^{\circ} \mathrm{C}, 700^{\circ} \mathrm{C}, 800^{\circ} \mathrm{C}, 900^{\circ} \mathrm{C}$ and $1000^{\circ} \mathrm{C}$ are shown in Fig. 3 As combustion temperatures increased from $575^{\circ} \mathrm{C}$ to $1000^{\circ} \mathrm{C}$, the microstructure of two 
ash samples both changed dramatically [23].

As shown in Fig.3, under $575^{\circ} \mathrm{C}$, abundant dispersed irregular particles were observed at a magnification of 10000 . Ash under $700^{\circ} \mathrm{C}$ aggregated to generate larger irregular aggregates, but it maintained a loose and porous structure. Under $800^{\circ} \mathrm{C}$, ash slightly sintered with the decrease in porosity and increase in density. While ash under $900^{\circ} \mathrm{C}$ sintered further with particles linking tightly to form homogeneous dense aggregates by partial fusion. For MSS ash under $900^{\circ} \mathrm{C}$, a large amount of unmelted fine crystal particles with diameters about 0.5 microns were also visible in outer space of aggregates. Under a magnification of 1000 , MSS ash at $1000^{\circ} \mathrm{C}$ showed continuous phases and a dense structure with abundant fine particles trapped in it, and abundant spherical voids smaller than 10 microns were visible in the cross section. The voids were mainly due to the decomposition of salts and release of gases from ash melt $[23,24]$. And the density and hardness of MSS ash under $1000^{\circ} \mathrm{C}$ were extremely high, which indicated that MSS ash was nearly totally sintered and melted under $1000^{\circ} \mathrm{C}$.

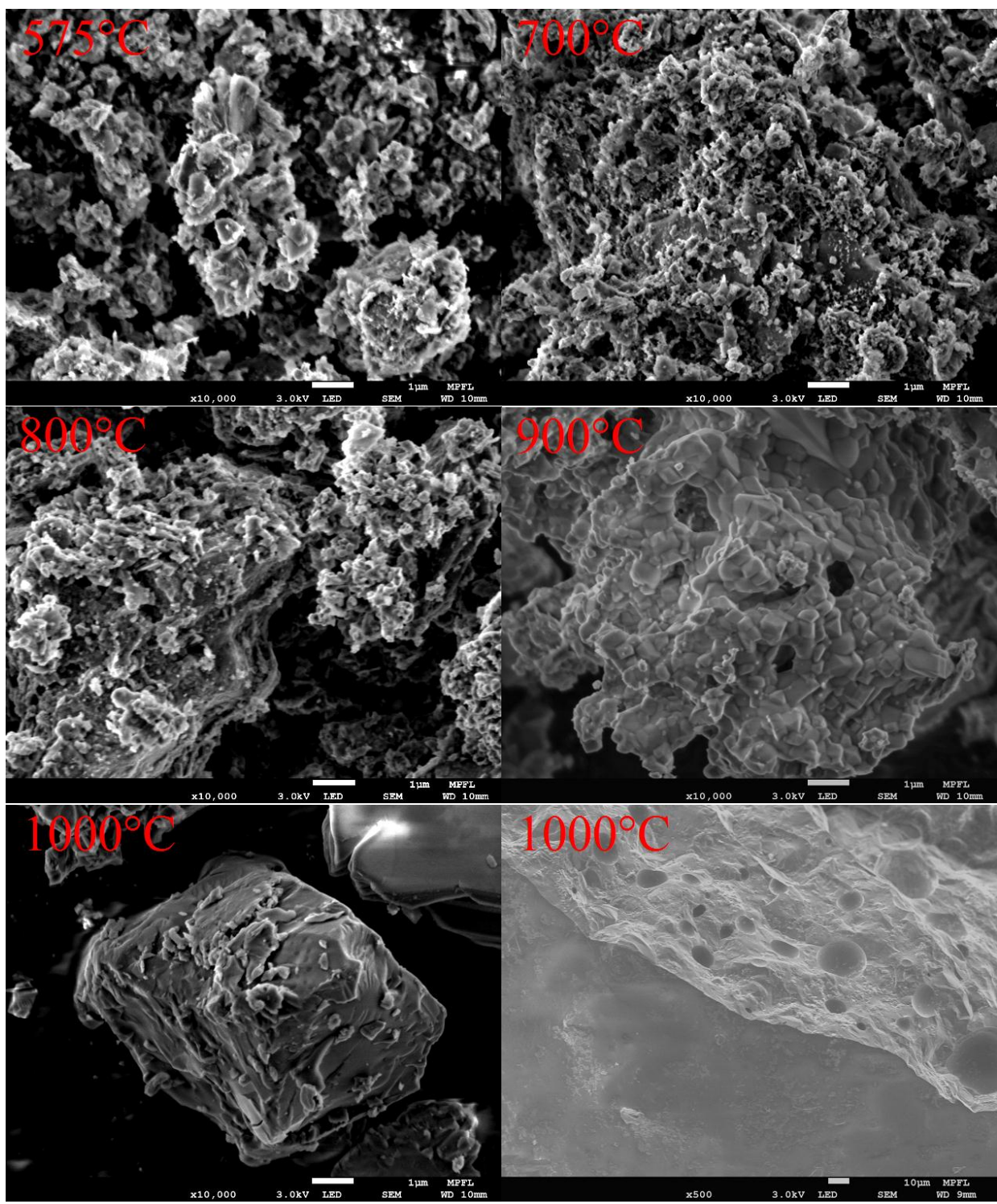

Fig.3. SEM images of ash samples of MSS prepared at $575^{\circ} \mathrm{C}, 700^{\circ} \mathrm{C}, 800^{\circ} \mathrm{C}, 900^{\circ} \mathrm{C}$ and $1000^{\circ} \mathrm{C}$ 
At a macro level, ash samples under $575^{\circ} \mathrm{C}, 700^{\circ} \mathrm{C}$ and $800^{\circ} \mathrm{C}$ present powder, while ash samples under $900^{\circ} \mathrm{C}$ and $1000^{\circ} \mathrm{C}$ present massive texture. The color of ash samples gradually changed from brown to redish brown. Whether from the macroscopic level or microscopic level, it's evident that MSS has an apparent tendency of fusion and sintering under temperature higher than $900^{\circ} \mathrm{C}$. The secure combustion temperature of MSS is lower than $800^{\circ} \mathrm{C}$ and the ash sintering product under $1000^{\circ} \mathrm{C}$ can be used as high strength materials [24, 25].

Fig.4 illustrated the XRD patterns of the ashes of MSS at different temperatures from $575^{\circ} \mathrm{C}$ to $1000^{\circ} \mathrm{C}$. The intensities of peaks were able to indicate the amount of corresponding minerals to a certain extent. The main mineral crystal of MSS ash prepared at $575^{\circ} \mathrm{C}$ was quartz $\left(\mathrm{Q}, \mathrm{SiO}_{2}\right)$, and there was also a small amount kyanite $\left(\mathrm{K}, \mathrm{Al}_{2} \mathrm{SiO}_{5}\right)$. The peaks of hematite $\left(\mathrm{H}, \mathrm{Fe}_{2} \mathrm{O}_{3}\right)$ were found at the $\mathrm{X}$-ray diffraction pattern of MSS ash with temperature increasing to $800^{\circ} \mathrm{C}$, and the peaks of $\mathrm{H}$ got a higher intensity as temperature increases further. High temperature promoted the crystallization of $\mathrm{H}$. With the temperature increasing, the peak intensity of $\mathrm{K}$ present increased firstly and then decreased. The peaks of $\mathrm{Q}$ had no significant changes with temperature changing from $575^{\circ} \mathrm{C}$ to $900^{\circ} \mathrm{C}$, but got weakened significantly when temperature increased from $900^{\circ} \mathrm{C}$ to $1000^{\circ} \mathrm{C}$, which indicated that quartz reacted with other materials to generate other complex minerals and then transfered to materials in glassy phase [26].

\section{Conclusions}

1) There were four main stages during combustion process of MSS: dehydration, de-volatilization and combustion of volatile, combustion of char and residual organics, and burnout. The increase in heating rate delayed but strengthened the combustion process.

2) Ash samples of MSS under $900^{\circ} \mathrm{C}$ and $1000^{\circ} \mathrm{C}$ sintered and melted severely to present massive texture. To prevent severe sintering or fusion, it is essential to control the combustion temperature lower than $900^{\circ} \mathrm{C}$.

3) The main minerals in sewage sludge ash were quartz $\left(\mathrm{SiO}_{2}\right)$ and hematite $\left(\mathrm{Fe}_{2} \mathrm{O}_{3}\right)$. Temperature higher than $800^{\circ} \mathrm{C}$ promoted the crystallization of hematite. High temperature of $1000^{\circ} \mathrm{C}$ promoted reactions between $\mathrm{SiO}_{2}$ and other materials to form eutectic compounds with low melting point, leading to severe sintering and melting of MSS ash.

4) To improve the combustion property of sewage sludge, the further work will focus on the cocombustion of municipal sewage sludge and various biomasses.

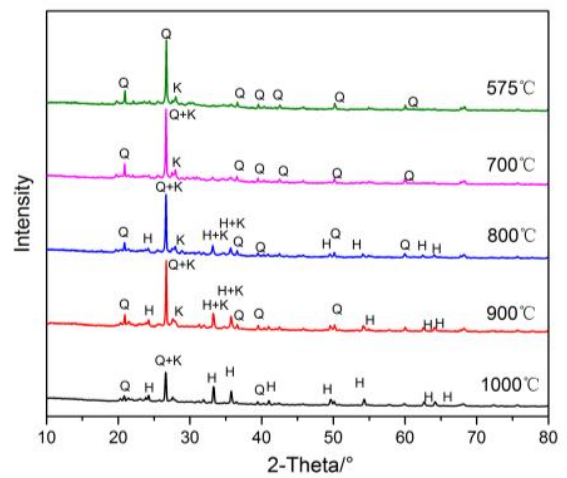

Fig.4. XRD spectrograms of MSS ash prepared at $575^{\circ} \mathrm{C}, 700^{\circ} \mathrm{C}, 800^{\circ} \mathrm{C}, 900^{\circ} \mathrm{C}$ and $1000^{\circ} \mathrm{C}$

\section{Acknowledgements}

This work was financially supported by Keypoint Research and Invention Program of Shaanxi Province of China (No. 2018ZDXM-SF-033). 


\section{References}

[1] Werther J, Ogada T. Sewage sludge combustion. Progress in Energy and Combustion Science, 1999; 25(1): 55-116.

[2] Cieślik BM., Namieśnik J, Konieczka P. Review of sewage sludge management: standards, regulations and analytical methods. Journal of Cleaner Production, 2015; 90: 1-15.

[3] Werle S, Wilk RK. A review of methods for the thermal utilization of sewage sludge. The Polish Perspective. Renewable Energy, 2010; 35(9):1914-1919.

[4] Kacprzak M, Neczaj E, Fijałkowski K, Grobelak A, Grosser A. et al. Sewage sludge disposal strategies for sustainable development. Environmental Research, 2017; 156: 39-46.

[5] Kelessidis A, Stasinakis AS. Comparative study of the methods used for treatment and final disposal of sewage sludge in European countries. Waste Management, 2012; 32(6): 1186-1195.

[6] Yang G, Zhang G, Wang HC. Current state of sludge production, management, treatment and disposal in China. Water Research, 2015; 78: 60-73.

[7] Hao ZD, Yang BQ, Jahng D. Combustion characteristics of biodried sewage sludge. Waste Management, 2018; 72: 296-305.

[8] Samolada MC, Zabaniotou AA. Comparative assessment of municipal sewage sludge incineration, gasification and pyrolysis for a sustainable sludge-to-energy management in Greece. Waste Management, 2014; 34(2): 411-420.

[9] Syed-Hassan Syed Shatir A, Wang Y, Hu S, Su S, Xiang J. Thermochemical processing of sewage sludge to energy and fuel: Fundamentals, challenges and considerations. Renewable and Sustainable Energy Reviews, 2017; 80: 888-913.

[10] Fu FL, Wang Q. Removal of heavy metal ions from wastewaters: A review. Journal of Environmental Management, 2011;92(3):407-418.

[11] Long B. Research of biomass ash characteristics based on ash composition. Master Dissertation. School of Energy and Engineering, Central South University, Changsha, Hunan, China; 2012.

[12] Niu SB, Chen MQ, Li Y, Song JJ. Co-combustion characteristics of municipal sewage sludge and bituminous coal. Journal of Thermal Analysis and Calorimetry, 2018; 131(2): 1821-1834.

[13] Huang LM, Xie C, Liu JY, Zhang XC, Chang KL et al. Influence of catalysts on co-combustion of sewage sludge and water hyacinth blends as determined by TG-MS analysis. Bioresource Technology, 2018; 247: 217-225.

[14] Huang LM, Liu JY, He Y, Sun SY, Chen JC. Thermodynamics and kinetics parameters of co-combustion between sewage sludge and water hyacinth in $\mathrm{CO}_{2} / \mathrm{O}_{2}$ atmosphere as biomass to solid biofuel. Bioresource Technology, 2016; 218: 631-642.

[15] Jiang, Long-bo, Yuan, Xing-zhong, Li, Hui, Chen, Xiao-hong, Xiao, Zhi-hua. et al., Co-pelletization of sewage sludge and biomass: Thermogravimetric analysis and ash deposits. Fuel Processing Technology, 2016; 145: 109-115.

[16] Kijo-Kleczkowska, Agnieszka, Środa, Katarzyna, Kosowska-Golachowska, Monika, Musiał, Tomasz, Wolski, Krzysztof et al., Combustion of pelleted sewage sludge with reference to coal and biomass. Fuel, 2016; 170: 141-160.

[17] Nunes LJR., Matias JCO, Catalão JPS. Biomass combustion systems: A review on the physical and chemical properties of the ashes. Renewable and Sustainable Energy Reviews, 2016; 53: 235-242.

[18] Li Meiyan, Xiao Benyi, Wang Xu, Liu Junxin. Consequences of sludge composition on combustion performance derived from thermogravimetry analysis. Waste Management, 2015; 35: 141-147.

[19] Font R, Fullana A, Conesa J A, Llavador F. Analysis of the pyrolysis and combustion of different sewage sludges by TG. Journal of Analytical and Applied Pyrolysis. 2001; 58: 927 - 941.

[20] Font R, Fullana A, Conesa J. Kinetic models for the pyrolysis and combustion of two types of sewage sludge. Journal of Analytical and Applied Pyrolysis, 2005; 74(1-2): 429-438.

[21] Wang H, Jiang XM, Liu JG, Yu LJ, Zhang QY. Analysis of pyrolytic properties of coal-water slurry under various heating rates. Journal of Power Engineering(in Chinese), 2007; 27(2):263-266.

[22] Hu SC, Ma XQ, Lin YS, Yu ZS, Fang SW. Thermogravimetric analysis of the co-combustion of paper mill sludge and municipal solid waste. Energy Conversion and Management, 2015; 99:112-118.

[23] Wang L, Skjevrak G, Hustad JE, Grønli MG. Sintering characteristics of sewage sludge ashes at elevated temperatures. Fuel Processing Technology, 2012; 96: 88-97.

[24] Magdziarz A, Wilk M, Gajek M, Nowak-Woźny D, Kopia, Agnieszka. et al. Properties of ash generated during sewage sludge combustion: A multifaceted analysis. Energy, 2016; 113: 85-94.

[25] Wang L, Skreiberg Ø, Becidan M, Li HL. Sintering of Rye Straw Ash and Effect of Additives. Energy Procedia, 2014; 61:2008-2011.

[26] Wang L, Skreiberg Ø, Becidan M, Li HL. Investigation of rye straw ash sintering characteristics and the effect of additives. Applied Energy, 2016; 162:1195-1204. 